\title{
Pemberdayaan Masyarakat Konsumen melalui Peningkatan Pemahaman terhadap Label Produk Pangan Olahan
}

\author{
Sunaryo*, M. Fakih, Kasmawati \\ Hukum Perdata, Universitas Lampung, Bandar Lampung, 35145, Lampung, Indonesia
}

\begin{abstract}
Abstrak.
Permasalahan dalam kegiatan ini adalah: 1) para siswa pada umumnya belum mengetahui tentang arti penting dan manfaat label yang tercantum dalam kemasan produk pangan; 2) masih adanya perilaku dari siswa yang tidak peduli atau memperhatikan label pada kemasan produk sewaktu mereka membeli suatu produk pangan; dan masih banyak diantara para siswa yang belum memahami mengenai keberadaan pengaturan tentang perlindungan konsumen khususnya tentang hak dan kewajian konsumen terkait dengan labelisasi produk pangan olahan.Pemecahan masalah tersebut dilakukan dengan carasosialisasi atau penyuluhan hukum tentang labelisasi produk pangan olahan. Melalui kegiatan penyuluhan ini, diharapkan dapat terjadi transformasi pengetahuan sehingga akan meningkatkan pemahaman yang mana nantinya diharapkan terjadi perubahan sikap perilaku mereka sesuai dengan pesan yang disampaikan. Hasil kegiatan menunjukkan telah terjadi peningkatan pengetahuan dan pemahaman pada khalayak sasaran, terhadap peraturan tentang label produk pangan olahan. Hal ini ditunjukkan dari hasil evaluasi, yaitu dari 58,86 (evaluasi awal) meningkat menjadi 75,23 (evaluasi akhir). Keberhasilan dari kegiatan penyuluhan ini didukung oleh antusias peserta sendiri dan kepala sekolah beserta dewan guru setempat.Berdasarkan kegiatan penyuluhan ini, masih perlu adanya tindakan lanjutan berupa penyuluhan dengan materi hukum yang terkait dengan label produk pangan olehan dan perlindungan konsumen.
\end{abstract}

Kata kunci.

Konsumen; Label Produk Pangan Olahan; Pemberdayaan.

\section{PENDAHULUAN}

\section{Analisis Situasi}

Perlindungan konsumen merupakan salah satu masalah yang mendasar dalam konstelasi pembangunan nasional Indonesia. Masalah perlindungan konsumen juga mempunyai dimensi yang sangat luas karena menjangkau dan menjadi kepentingan semua lapisan masyarakat. Seluruh rakyat Indonesia adalah konsumen begitu juga para pelaku usaha melekat pada dirinya posisi sebagai konsumen. Melihat posisi konsumen yang

\section{* Corresponding author: sunaryo.1960@fh.unila.ac.id}

Received 20 November 2020; Received in revised form 30 November 2020; Accepted 10 December 2020 Available online 24 December 2020

Lembaga Penelitian dan Pengabdian Kepada Masyarakat

Universitas Lampung 
demikian ini, maka pengusaha tidak bisa lagi memandang konsumen sebelah mata dan hanya dipandang sebagi objek di dalam menjalankan usahanya. Pandangan para pelaku usaha harus berubah dari doktrin caveat emptor yang menuntut konsumen untuk senantiasa berhati-hati kepandangan doktrin caveat venditor dimana pelaku usahalah yang harus waspada. Dewasa ini pelaku usaha tidak bisa lagi hanya berorientasi pada keuntungan sesaat untuk jangka pendek, tetapi harus dapat eksis untuk jangka panjang dengan cara memperhatikan hak-hak normatif konsumen sebagai satu kesatuan di dalam menjalankan usahanya.

Sebelum dikeluarkannya Undang-Undang Perlindungan Konsumen pada tahun 1999, hak-hak normatif konsumen sebenarnya sudah diatur dalam berbagai peraturan perundangan tetapi pengaturannya belum komprehensif dan masih bersifat sektoral. Hal ini berbeda setelah Undang-Undang Perlindungan Konsumen Nomor 8 Tahun 1999 diundangkan dimana undang-undang ini sebagai payung hukum dalam perlindungan konsumen di Indonesia. Kehadiran Undang-Undang Perlindungan Konsumen ini perlu diberi apresiasi baik oleh konsumen maupun pelaku usaha, karena undang-undang ini merupakan parameter yang objektif dan normatif untuk menilai usaha di Indonesia. Adanya UndangUndang Nomor 8 Tahun 1999 ini bukan berarti pemerintah hanya memanjakan konsumen tetapi memberikan hak konsumen untuk mendapatkan produk barang/jasa yang berkualitas dan aman sesuai dengan harga yang dibayarkan. Dengan demikian kehadiran undangundang ini hendaknya dijadikan cambuk bagi pelaku usaha untuk meningkatkan kepedulian kepada konsumen dengan cara memberikan produk dan pelayanan yang memuaskan kepentingan konsumen.

Keberadaan Undang-Undang Nomor 8 Tahun 1999 di Indonesia bertujuan untuk meningkatkan harkat dan martabat konsumen melalui berbagai upaya, antara lain meningkatkan pengetahuan, kesadaran, kepedulian, dan kemandirian konsumen terutama dalam memilih, menentukan dan menuntut hak-haknya sebagai konsumen. Disamping itu undang-undang ini juga bertujuan untuk menciptakan sistem perlindungan konsumen dengan memberikan kepastian hukum serta keterbukaan informasi sekaligus menumbuhkan kesadaran pelaku usaha tentang pentingnya perlindungan konsumen. Dengan demikian diharapakan akan tumbuh sikap jujur dan bertanggung jawab dalam berusaha dengan menghasilkan barang/jasa yang berkualitas sehingga dapat menjamin kelangsungan usaha, kenyamanan, keamanan dan keselamatan konsumen.

Terkait dengan tujuan di atas, maka Undang-Undang Perlindungan Konsumen melarang pelaku usaha memproduksi dan/atau memperdagangkan barang dan/atau jasa yang tidak memasang label atau membuat penjelasan barang yang memuat nama barang, ukuran, berat/isi bersih atau netto, komposisi, aturan pakai, tanggal pembuatan, akibat sampingan, nama dan alamat pelaku usaha serta keterangan lain untuk penggunaan yang menurut ketentuan harus dipasang atau dibuat. Kewajiban pemasangan label baik label produksi maupun label halal pada suatu produk barang atau jasa bagi pelaku usaha ini merupakan salah satu upaya pemerintah dalam melindungi kepentingan konsumen. Melaui label yang terpasang pada suatu produk barang atau jasa, konsumen akan memperoleh informasi yang sangat penting dan dibutuhkan terkait dengan keberadaan barang atau jasa yang akan dibeli atau dikonsumsi. Mengingat pentingnya informasi atas suatu produk barang atau jasa bagi konsumen ini, maka Undang-Undang Nomor 8 tahun 1999 tidak hanya menetapkan sebagai salah satu hak konsumen tetapi sekaligus mewajibkan pelaku usaha untuk memberikan informasi dimaksud secara benar, jelas dan jujur mengenai kondisi dan jaminan barang atau jasa yang dihasilkan.

Hak atas informasi di atas hanya akan dapat dirasakan manfaatnya oleh konsumen apabila konsumen tersebut mengetahui dan memahami makna dari isi informasi yang tercantum dalam label. Oleh karena itu disamping hak atas informasi, Undang-Undang Nomor 8 tahun 1999 juga memberikan hak bagi konsumen untuk mendapatkan pembinaan dan pendidikan tentang konsumen. Pendidikan konsumen (consumer education) merupakan suatu conditio sine qua-non untuk mencapai masyarakat yang sadar hukum. Pentingnya pendidikan konsumen ini oleh Jorge Osorio [1] dinyatakan sebagaimana juga pendidikan hak asasi manusia dan lingkungan merupakan pendidikan etika dan nilai. 
Pendidikan konsumen ini adalah instrumen penting bagi pemberdayaan konsumen itu sendiri. Pendidikan ini dapat dilakukan melalui program belajar formal atau melalui teknik pendidikan populer, dengan penekanan dari kesadaran akan hak konsumen, penyuluhan dan kemampuan berorganisasi.

Dengan berlakunya Undang-Undang Nomor 8 Tahun 1999, pendidikan konsumen menjadi hal yang penting untuk dilaksanakan secara terprogram, terarah, dan berkelanjutan. Melalui pendidikan konsumen masyarakat akan mengetahui dan memahami hak-hak meraka sebagai konsumen. Undang-undang Perlindungan Konsumen tidak akan banyak bermanfaat bagi masyarakat (konsumen) jika masyarakat (konsumen) itu sendiri tidak mempunyai kesadaran hukum untuk melaksanakannya. Oleh karena itu upaya memberdayakan konsumen melalui berbagai bentuk pendidikan konsumen (melalui sosialisasi Undang-Undang Nomor 8 Tahun 1999) perlu dilakukan guna membangun dan meningkatkan kesadaran hukum atas hak-hak mereka sebagai konsumen.

Para siswa Sekolah Menengah Atas Negeri 1 Gading Rejo pada dasarnya semuanya adalah konsumen baik terhadap produk barang atau jasa yang dihasilkan oleh pelaku usaha. Menurut informasi awal dari Kepada Sekolah setempat, masih banyak di antara siswa di sekolahnya yang belum mengetahui terlebih memahami hak-hak konsumen sebagaimana yang diatur di dalam Undang-Undang Nomor 8 Tahun1999. Salah satu hak konsumen yang penting adalah hak atas informasi yang benar, jelas, dan jujur atas kondisi barang atau jasa yang dia beli atau konsumsi. Para siswa ini pada umumnya tidak begitu peduli atau memperhatikan informasi yang tercantum dalam label kemasan baik label produksi maupun label halal atas suatu produk barang (pangan) yang mereka beli atau konsumsi. Keadaan ini tentu saja disamping bisa berakibat merugikan konsumen itu sendiri juga bisa dimanfaatkan oleh pelaku usaha yang tidak bertanggung jawab.

Para siswa ini pada umumnya tidak begitu peduli atau memperhatikan informasi yang tercantum dalam label kemasan baik label produksi maupun label halal atas suatu produk barang (pangan) yang mereka beli atau konsumsi. Keadaan ini tentu saja disamping bisa berakibat merugikan konsumen itu sendiri juga bisa dimanfaatkan oleh pelaku usaha yang tidak bertanggung jawab.

\section{Identifikasi dan Perumusan Masalah}

Berdasarkan hasil prasurvei di Sekolah Menengah Atas Negeri 1 Gading Rejo Kabupaten Pringsewu, dapat dikemukakan situasi sebagai berikut:

1. Para siswa pada umumnya belum mengetahui tentang arti penting dan manfaat label yang tercantum dalam kemasan produk pangan yang mereka beli atau konsumsi.

2. Masih adanya perilaku dari siswa yang tidak peduli atau memperhatikan label pada kemasan produk sewaktu mereka membeli suatu produk pangan.

3. Masih banyak diantara para siswa yang belum memahami mengenai keberadaan pengaturan tentang perlindungan konsumen khususnya tentang hak dan kewajian konsumen dan pelaku usaha terkait dengan labelisasi produk pangan olahan.

Berdasarkan adanya kenyataan di atas, maka perumusan masalah dalam kegiatan pengabdian kepada para siswa di Sekolah Menengah Atas Negeri 1 Gadingrejo adalah: Bagaimana upaya yang dilakukan untuk lebih memberdayakan masyarakat konsumen dalam hal ini para siswa di Sekolah Menengah Atas Negeri 1 Gadingrejo melalui peningkatan pengetahuan dan pemahaman tentang arti penting dan manfaat label yang tercantum dalam kemasan produk pangan olahan bagi para siswa?

\section{Tujuan Kegiatan}

Secara umum tujuan dari kegiatan penyuluhan hukum ini adalah untuk lebih memberdayakan masyarakat, khususnya bagi para pelajar/siswa SMAN 1 Gadingrejo melalui peningkatan pengetahuan dan pemahaman mereka terhadap ketentuan-ketentuan yang terkait dengan label produk pangan olahan, sehingga akan tercipta kesadaran hukum 
yang tinggi di dalam menentukan sikap terhadap suatu produk yang akan dikonsumsinya.

Sedangkan secara lebih khusus, kegiatan ini bertujuan untuk:

1. Meningkatkan pengetahuan dan pemahaman masyarakat khususnya para pelajar/siswa SMAN 1 Gadingrejo terhadap ketentuan-ketentuan yang terkait dengan label produk pangan olahan.

2. Setelah memperoleh pengetahuan dan pemahaman diharapkan masyarakat (dalam hal ini pelajar/siswa SMAN 1 Gadingrejo) selanjutnya akan memiliki kesadaran hukum yang tinggi sehingga ada perubahan pola sikap yang menunjukkan ketaatannya pada peraturan sehingga akan terwujud suasana aman dan nyaman.

3. Meminimalisir terjadinya pelanggaran terhadap kewajiban melakukan labelisasi yang baik dan benar oleh para pelaku saha dan semakin berkurangnya risiko yang berpotensi sangat merugikan masyarakat konsumen.

\section{Manfaat Kegiatan}

Kegiatan pengabdian kepada masyarakat dalam bentuk penyuluhan hukum ini diharapkan akan dapat memberikan beberapa manfaat, antara lain:

1. Pengetahuan dan pemahaman para pelajar/siswa SMAN 1 Gadingrejo terhadap ketentuan yang terkait dengan label produk pangan olahan akan meningkat.

2. Menumbuhkan dan mendorong para pelajar/siswa SMAN 1 Gadingrejo untuk berperilaku hati-hati di dalam memilih dan mengkonsumsi produk makanan olahan yang sehat dan aman.

3. Diharapkan dapat meminimalisir terjadinya pelanggaran oleh para pelaku usaha terhadap kewajiban labelisasi produk pangan secara baik dan benar, serta dapat menekan terjadinya kerugian bagi masyarakat konsumen akibat mengkonsumsi suatu produk pangan olahan.

\section{KERANGKA TEORI}

Hukum baik sebagai kaedah atau sebagai perilaku, pada hakekatnya merupakan suatu pesan. Pesan tersebut tertuju baik kepada warga masyarakat secara umum, maupun pembuat hukum itu sendiri. Oleh karena itu, hukum harus disampaikan kepada suatu khalayak (audience) tertentu. Apabila hukum tidak disampaikan secara aktif dan kontinyu kemungkinan kecil hukum tersebut mempunyai efek terhadap perilaku manusia, baik secara pribadi maupun di dalam kehidupan berkelompok.

Sebagai suatu pesan, maka hukum pada dasarnya suatu kaidah atau norma sebagai pedoman bagi manusia di dalam melakukan hubungannya dengan orang lain agar tercipta suasana tertib dan teratur. Dalam hal ini Soleman B.Taneko [2] menyatakan bahwa hukum mempunyai fungsi sebagai pedoman kepada warga masyarakat bagaimana mereka harus bertingkah laku atau bersikap dalam menghadapi masalah-masalah yang terutama menyangkut kebutuhan pokok. Kondisi masyarakat yang tertib dan teratur sebagaimana diharapkan di atas tentu hanya akan terwujud manakala setiap orang dalam masyarakat melaksanakan isi ketentuan dari kaidah atau norma tersebut di dalam setiap aktivitasnya. Terkait hal ini, Sudikno Mertokusumo [3] menegaskan, bahwa kaidah hukum bukanlah sekedar pedoman yang beku saja, tetapi harus ditaati atau dipatuhi.

Oleh karena itu, bunyi slogan yang dikenal dalam ilmu hukum "semua orang dianggap tahu hukum/undang-undang" merupakan suatu pernyataan yang tidak akan mampu membantupeningkatan pemahaman hukum atau kesadaran hukum masyarakat [4]. Menghadapi persoalan yang demikian itu, maka perlu dikembangkan usaha penyebarluasan informasi mengenai hukum, mengenai isi normatif suatu hukum, juga mengenai ide-ide pembenarnya.

Tegaknya hukum, sesungguhnya tidak semata-mata dibebankan pada para penegak 
hukum saja akan tetapi lebih efektif kalau diusahakan oleh para pemegang hak. Oleh sebab itu, komunikasi hukum yang terselenggara dengan baik akan menyadarkan warga yang mendukung kewajiban untuk mentaati ketentuan- ketentuan hukum. Selain itu, dengan komunikasi yang baik juga menyadarkan masyarakat lain akan tersedianya hak baru yang diberikan oleh hukum.

Proses komunikasi bukanlah tindakan yang bersifat insidental tetapi merupakan kegiatan yang berkesinambungan. Friedmaan [5] mengemukakan pentingnya komunikasi hukum "a legal act (rule, doctrins, practice) whateve functions it serves, is message". Komunikasi dalam arti sebenarnya merupakan suatu penyampaian dan penerimaan lambang-lambang yang mengandung arti-arti tertentu.Berbeda dengan komunikasi pada taraf pengkhabaran saja, yang tidak ada pola edukatif secara intensif kepada warga masyarakat.Oleh karena itu produk undang-undang yang dikeluarkan oleh negara kalau sampai pada taraf pengkhabaran saja sulit memperoleh hasilnya yang maksimum maupun optimum.

Tujuan komunikasi adalah untuk menciptakan pengertian bersama, dengan maksud agar terjadi perubahan pikiran sikap dan perilaku. Komunikasi hukum lebih banyak tertuju pada sikap, oleh karenannya sikap merupakan suatu kesiapan mental (predisposition), sehingga seseorang mempunyai kecenderungan-kecenderungan untuk memberikan pandangan yang baik dan buruk, yang kemudian terwujud dalam perilaku nyata.Dengan demikian, sikap mempunyai komponen kognitif, afektif, maupun konatif. Komponen kognitif menyangkut persepsi terhadap keadaan sekitarnya yang antara lain mencakup pengetahuan. Komponen afektif berhubungan dengan perasaan senang atau tidak senang (yaitu yang posif dan negatif). Komponen konatif berkaitan dengan kecenderungan untuk bertindak atau untuk berbuat sesuatu. Ketiga komponen tersebut menurut Soerjono Soekanto [6] berkaitan dengan komunikasi hukum.

Dengan demikian usaha komunikasi tidak lain adalah untuk membangkitkan compliance (ketulusan atau kerelaan dalam mentaati hukum) dan perlu diawali dengan penyebarluasan isi hukum yang tengah berlaku. Berdasarkan pada kerangka pemikiran di atas, maka dalam bidang hukum perlindungan konsumen khususnya yang terkait dengan hak-hak konsumen dan masalah labelisasi baik label produksi maupun label halal perlu dikomunikasikan. Proses komunikasi hukum yang dilakukan adalah melalui sosialisasi atau penyuluhan tentang peraturan perundangan dimaksud kepada masyarakat luas (konsumen).

Sosialisasi atau penyuluhan hukum merupakan pendidikan hukum yang penting untuk dilaksanakan guna mencapai kesadaran hukum masyarakat. Mengingat posisi yang demikian itu, maka melalui UN Guidelines forConsumers rotection setiap Negara wajib menciptakan dan mengembangkan program pendidikan dan penyuluhan bagi konsumen secara umum dengan memperhatikan aspek budaya dan tradisi masyarakat. Tujuan program tersebut harus memungkinkan masyarakat sebgai konsumen harus berhati-hati dalam membeli barang, dapat melakukan pilihan terhadap barang dan jasa dan sadar akan hak dan tanggung jawab mereka. Dalam mengembangkan program tersebut, perhatian khusus harus memenuhi keperluan konsumen dipedesaan maupun perkotaan termasuk konsumen berpenghasilan dan berpendidikan rendah. Apabila perlu, pendidikan konsumen menjadi bagian yang tidak terpisahkan dengan kurikulum dasar sistem pendidikan, terutama sebagai komponen sistem pendidikan yang ada.

Program penyuluhan dan pendidikan konsumen harus memenuhi aspek-aspek penting dalam perlindungan konsumen. Aspek-aspek penting dimaksud antara lain adalah produk yang memiliki label atau merek, dan informasi mengenai ukuran, berat dan timbangan, harga, mutu, persyaratan kredit serta tersedianya kebutuhan dasar. Selanjutnya guna mencapai hasil yang maksimal, negara wajib mengorganisir atau mendorong program ini kepada semua pihak agar memungkinkan mereka berperan serta mengembangkan program penyuluhan dan bimbingan konsumen.

Keberadaan Undang-Undang Perlindungan Konsumen haruslah selalu diupayakan oleh semua pihak agar masyarakat mulai memanfaatkan undang-undang ini. Sosialisasi untuk menyadarkan potensi konsumen atas produk hukum ini harus senantiasa dilaksanakan, agar seluruh anggota masyarakat mengetahui dan memahami akan hak-hak mereka 
sebagai konsumen. Penyadaran potensi konsumen merupakan salah satu faktor dalam rangka pemberdayaan konsumen.

Faktor lain yang juga sangat mempengaruhi keberhasilan dalam upaya pemberdayaan konsumen adalah faktor pembentukan sikap konsumen dan sosialisasi Undang-Undang Perlindungan Konsumen itu sendiri. Tidak akan banyak bermanfaat undang-undang ini jika tidak disosialisasikan dan masyarakat tidak mengetahuinya Disamping faktor-faktor di atas, menurut Aman Sinaga [1] sebagai ikhtiar tercapainya pemberdayaan konsumen, maka konsumen pun harus memiliki sikap, antara lain bersikap kritis, berani bertindak, memiliki kepedulian sosial dan lingkungan, serta memiliki rasa setia kawan. Partisipasi masyarakat (konsumen) dalam penegakan hukum perlindungan konsumen sangat diperlukan. Tanpa adanya inisiatif, peran, dan keterlibatan konsumen, hukum perlindungan konsumen tidak akan bisa berfungsi dengan baik.

Penjelasan di atas menunjukkan bahwa dalam upaya pemberdayaan masyarakat sangat terkait dengan masalah kesadaran hukum masyarakat. Kesadaran hukum merupakan salah satu ciri bahwa masyarakat telah memahami dan mengerti hukum.Kesadaran hukum warga negara dapat terlihat dari perilaku dimana dia berada. Kesadaran hukum adalah kesadaran yang ada pada setiap manusia tentang apa hukum itu atau apa seharusnya hukum itu, suatu kategori tertentu dari hidup kejiwaan kita dengan mana kita membedakan antara hukum dan tidak hukum (onrecht), antara yang seyogyanya dilakukan dan tidak seyogyanya dilakukan.

Kesadaran hukum mempunyai beberapa konsepsi, salah satunya konsepsi mengenai kebudayaan hukum.Konsepsi ini mengandung ajaran-ajaran kesadaran hukum lebih banyak mempermasalahkan kesadaran hukum yang dianggap sebagai mediator antara hukum dengan perilaku manusia, baik secara individual maupun kolektif. Menurut Soerjono Soekanto [7] kesadaran hukum sebenarnya merupakan kesadaran atau nilai-nilai yang terdapat di dalam diri manusia tentang hukum yang ada atau tentang hukum yang diharapkan ada. Sebenarnya yang ditekankan adalah nilai-nilai tentang fungsi hukum dan bukan suatu penilaian hukum terhadap kejadian-kejadian yang konkrit dalam masyarakat yang bersangkutan.

Lebih lanjut Soerjono Soekanto [7] menyatakan bahwa indikator-indikator dari kesadaran hukum sebenarnya merupakan petunjuk yang relatif kongkrit tentang taraf kesadaran hukum. Dijelaskan lagi secara singkat bahwa:

1. Indikator pertama adalah pengetahuan hukum.

Seseorang mengetahui bahwa perilaku-perilaku tertentu itu telah diatur oleh hukum. Peraturan hukum yang dimaksud disini adalah hukum tertulis maupun hukum yang tidak tertulis. Perilaku tersebut menyangkut perilaku yang dilarang oleh hukum maupun perilaku yang diperbolehkan oleh hukum.

2. Indikator kedua adalah pemahaman hukum.

Seseorang warga masyarakat mempunyai pengetahuan dan pemahaman mengenai aturan-aturan tertentu, misalnya adanya pengetahuan dan pemahaman yang benar dari masyarakat tentang hakikat dan arti pentingnya UU No. 1 Tahun 1974 tentang perkawinan.

3. Indikator yang ketiga adalah sikap hukum.

Seseorang mempunyai kecenderungan untuk mengadakan penilaian tertentu terhadap hukum.

4. Indikator yang keempat adalah perilaku hukum,

Seseorang atau dalam suatu masyarakat warganya mematuhi peraturan yang berlaku.

Berdasarkan keempat indikator tersebut di atas, menunjukkan tingkatan-tingkatan pada kesadaran hukum tertentu di dalam perwujudannya. Apabila seseorang mengetahui hukum.maka bisa dikatakan bahwa tingkat kesadaran hukumnya masih rendah. Akan tetapi, kalau seseorang atau suatu masyarakat telah berperilaku sesuai hukum, maka tingkat kesadaran hukumnya telah tinggi. 


\section{KERANGKA PEMECAHAN MASALAH DAN REALISASINYA}

\section{Kerangka Pemecahan Masalah}

Sebagaimana dipaparkan sebelumnya bahwa pada umumnya tingkat pengetahuan dan pemahaman masyarakat, khususnya pada pelajar/siswa SMAN 1 Gadingrejo terhadap ketentuan label produk pangan olahan masih rendah. Oleh karena itu, solusi untuk mengatasi masalah tersebut di atas, diperlukan adanya proses pengajaran dan pendidikan kaidah-kaidah hukum khususnya tentang labelisasi produk pangan olahan dalam bentuk sosialisasi atau penyuluhan hukum. Melalui kegiatan penyuluhan ini, diharapkan cukup efektif dalam mentransformasi pengetahuan mengenai ketentuan hukum atau peraturan tentang labelisasi produk pangan olahan yang berlaku.

Transformasi yang diberikan kepada masyarakat (siswa SMAN 1Gadingrejo) berupa pengetahuan hukum tentang label produk meliputi arti penting label, manfaat label, isi atau keterangan serta berbagai sanksi atas pelanggaran di dalam pencantuman label pada kemasan produk pangan. Dengan transformasikannya materi tersebut, mereka akan menerima pengetahuan baru dan mencapai pola sikap baru. Perubahan perilaku khalayak sasaran yang memperoleh penyuluhan hukum digambarkan sebagai berikut:

Tabel 1. Kerangka Solusi Masalah.

\begin{tabular}{|c|c|c|c|}
\hline No & Kondisi Awal & Perlakuan & Luaran Yang Dihasilkan \\
\hline 1 & $\begin{array}{l}\text { Siswa SMAN } 1 \text { belum mengetahui } \\
\text { dan memahami tentang pengertian } \\
\text { label }\end{array}$ & Ceramah dan diskusi & $\begin{array}{l}\text { Siswa SMAN } 1 \text { dapat mengetahui } \\
\text { dan memahami tentang pengertian } \\
\text { label }\end{array}$ \\
\hline 2 & $\begin{array}{l}\text { Siswa SMAN } 1 \text { belum mengetahui } \\
\text { dan memahami tentang arti penting } \\
\text { dan manfaat dari label produk } \\
\text { pangan olahan }\end{array}$ & Ceramah dan diskusi & $\begin{array}{l}\text { Siswa SMAN } 1 \text { dapat mengetahui } \\
\text { dan memahami arti penting dan } \\
\text { manfaat dari label produk pangan } \\
\text { olahan }\end{array}$ \\
\hline 3 & $\begin{array}{l}\text { Siswa SMAN } 1 \text { belum mengetahui } \\
\text { dan memahami tentang isi atau } \\
\text { keterangan dan tujuan dari label } \\
\text { produk pangan olahan }\end{array}$ & Ceramah dan diskusi & $\begin{array}{l}\text { Siswa SMAN } 1 \text { dapat mengetahui } \\
\text { dan memahami tentang isi atau } \\
\text { keterangan dan tujuan dari label } \\
\text { produk pangan olahan }\end{array}$ \\
\hline 4 & $\begin{array}{l}\text { Siswa SMAN } 1 \text { belum mengetahui } \\
\text { dan memahami tentang berbagai } \\
\text { sanksi atas pelanggaran } \\
\text { pencantuman label produk pangan } \\
\text { olahan }\end{array}$ & Ceramah dan diskusi & $\begin{array}{l}\text { Siswa SMAN } 1 \text { dapat mengetahui } \\
\text { dan memahami tentang berbagai } \\
\text { sanksi atas pelanggaran } \\
\text { pencantuman label produk pangan } \\
\text { olahan }\end{array}$ \\
\hline
\end{tabular}

\section{Realisasi Pemecahan Masalah}

Berdasarkan data dan informasi yang diperoleh, dapat diketahui bahwa masyarakat pelajar/siswa SMAN 1 Gadingrejoyang menjadi khalayak sasaran dalam kegiatan ini masih memiliki pengetahuan yang rendah tentang materi penyuluhan. Hal-hal yang terkait khususnya dengan informasi atau isi dari keterangan yang ada pada label kemasan produk pangan olahan. belum dimengerti dengan baik oleh para pelajar siswa SMAN 1 Gadingrejo. Oleh karena itu, untuk mengatasi permasalahan tersebut, siswa SMAN 1 Gadingrejo perlu ditingkatkan pemahamannya melalui suatu kegiatan sosialisasi hukum berupa penyuluhan hukum yang berhubungan dengan labelisasi produk apngan olahan dalam rangka untuk meminimalisir terjadinya kerugian akibat ketidaktahuan pentingnya mengetahui label pada kemasan produk pangan.

\section{HASIL DAN PEMBAHASAN}

\section{Evaluasi Terhadap Khalayak Sasaran}

Untuk mengetahui tingkat keberhasilan atau kegagalan sosialisasi ini, maka kepada khalayak sasaran perlu dilakukan evaluasi kegiatan. Evaluasi dilakukan secara spesifik untuk mengetahui tingkat pengetahuan dan pemahamannya terhadap materi yang disampaikan. Adapun langkah-langkah evalusinya meliputi: 
1. Evaluasi awal

Evaluasi awal dilakukan sebelum penyampaian materi, dengan maksud untuk mengetahui tingkat pengetahuan dan pemahaman tentang pengaturan label, pengertian dan arti pentingnya label, informasi atau isi dari label, serta hak dan kewajiban konsumen. Evaluasi ini dilakukan dengan menggunakan beberapa daftar pertanyaan mengenai aspek pengetahuan dan pemahaman khalayak sasaran terhadap materi hukum di atas. Perkembangan nilai antara evaluasi awal dengan evaluasi akhir tercantum dalam tabel terlampir. Adapun hasil rata-rata evaluasi awal dari 22 orang peserta baru mencapai 58,86 . Hal ini menunjukkan tingkat pengetahuan dan pemahaman peserta kegiatan tergolong rendah.

\section{Evaluasi proses}

Evaluasi proses dilakukan selama proses kegiatan sosialisasi hukum berlangsung. Evaluasi ini dilakukan dengan cara menilai partisipasi aktif peserta melalui sejumlah pertanyaan dan bobot pertanyaan yang diajukan. Peserta yang hadir ternyata memberikan sikap yang positif terhadap kegiatan ini. Selain itu, peserta selalu mengukapkan kasus-kasus yang terjadi mengenai berbagai jenis temuan dan pelanggaran dalam pencantuman label pada kemasan produk pangan olahan.

\section{Evaluasi akhir}

Evaluasi akhir digunakan dengan menggunakan daftar pertanyaan yang sama pada waktu pra-uji yang diselenggarakan pada akhir kegiatan. Evaluasi akhir bertujuan untuk mengetahui keberhasilan kegiatan sosialisasi dengan membandingkan pengetahuan dan pemahaman sebelum dan sesudah kegiatan dilakukan. Hasil yang dicapai para peserta ditunjukkan dengan melihat perkembangan hasil evaluasi akhir (En) dikurangi hasil evaluasi awal $(\mathrm{Ea})$ atau $\mathrm{K}=(\mathrm{En})$ - (Ea). Jika terjadi perubahan terhadap pengetahuan dan pemahaman hukum, yaitu dari tidak tahu menjadi tahu, dari tidak /kurang faham menjadi faham, maka sosialisasi ini dapat dikatakan berhasil.Tingkat perubahan kedua hal tersebut di atas dapat dilihat dari selisih antara hasil pra-uji dan hasil pasca-uji yang meliputi tingkat perubahan pemahaman. Jika hasil pra-uji lebih rendah, nilainya daripada setelah dilakukan kegiatan sosialisasi, atau hasil pasca-uji nilainya lebih tinggi daripada pra-uji, maka tingkat pencapaian pengetahuan khalayak sasaran kegiatan dapat dikatakan berhasil. Berdasarkan hasil evaluasi awal dan akhir maka diperoleh angka peningkatan, yaitu dari 58,86 (evaluasi awal) menjadi 75,23 (evaluasi akhir). Dengan demikian, disini telah terjadi peningkatan tingkat pengetahuan dan pemahaman tentang materi yang disajikan. Peningkatan pengetahuan dan pemahaman masyarakat meliputihal-hal tentang pengaturan label, pengertian dan arti pentingnya label, informasi atau isi dari label, cara pencantuman label, serta hak dan kewajiban konsumen.

\section{Faktor Pendukung dan Faktor Penghambat}

\section{Faktor Pendukung}

Keberhasilan dari kegiatan penyuluhan ini terutama didukung oleh:

a. Antusias khalayak sasaran yang benar-benar menginginkan adanya informasi tentang hukum yang mengatur mengenai labelisasi produk pangan olahan.

b. Adanya dukungan dari instansi dimana sosialisasi atau penyuluhan ini dilakukan, baik oleh Kepala SMAN 1 Gadingrejo maupun jajarananya para dewan guru setempat.

\section{Faktor Penghambat}

Dalam kegiatan penyuluhan ini pada dasarnya tidak banyak menemui faktor penghambat yang berarti. Hal ini disebabkan karena kegiatan penyuluhan dilaksanakan pada siang hari pada saat jam pelajaran, sehingga tidak mengganggu aktivitas rutinnya. Hanya saja waktu diadakannya penyuluhan sedang pada masa pandemi Covid-19 sehingga jumlah peserta tidak bisa maksimal karena memang 
dibatasi sesuai dengan protokol kesehatan.

\section{PENUTUP}

\section{Kesimpulan}

Berdasarkan pelaksanaan dan evaluasi yang telah dilaksanakan dari kegiatan penyuluhan ini, maka dapat disimpulkan sebagai berikut:

1. Kegiatan penyuluhan hukum ini cukup berhasil, yang ditandai dengan keaktifan peserta, baik dalam mengikuti dan menyimak penyajian materi maupun dalam kesempatan tanya jawab atau diskusi.

2. Adanya peningkatan pengetahuan dan pemahaman tentang hukum yang mengatur mengenai labelisasi produk pangan olahan. Hal ini ditunjukan dengan hasil evaluasi dari 58,86 (evaluasi awal) menjadi 75,23 (evaluasi akhir). Peningkatan pengetahuan dan pemahaman peserta meliputipengaturan label, pengertian dan arti pentingnya label, informasi atau isi dari label, cara pencantuman label, serta hak dan kewajiban konsumen. Diharapkan dengan meningkatnya pengetahuan dan pemahaman masyarakat tentang peraturan label tersebutakan meningkat pula kesadaran hukumnya. Keberhasilan dari kegiatan penyuluhan ini tidak terlepas dari dukungan dan antusias para siwa SMAN 1 Gadingrejo sebagai khalayak sasara serta adanya dukungan dari Kepala Sekolah dan dewan guru setempat.

\section{Saran}

Dengan adanya sambutan yang positif dari khalayak sasaran setempat terhadap kegiatan penyuluhan ini, maka perlu adanya tindak lanjut serta kontinuitas dari kegiatan tersebut. Kedepan, materi yang perlu disampaikan pada masyarakat bisa jadi bukan hanya kaidah/aturan-aturan hukum yang mengatur tentang labelisasi produk pangan olahan saja, tetapi dibidang lain seperti narkoba, kenakalan remaja, atau norma-normasosial lainnya. Hal ini disebabkan ditengarai masih banyaknya dikalangan masyarakat dan siswa yang belum mengetahui dan memahami secara detail dan komprehensif berbagai ketentuan hukum di atas. Oleh karena itu, penyampaian informasi tentang hukum melalui penyuluhanpenyuluhan kepada masyarakat dan siswa masih sangat diperlukan.

\section{DAFTAR PUSTAKA}

[1] Sinaga, Aman. 2001. Pemberdayaan Hak-Hak Konsumen Di Indonesia. Jakarta: Penerbit Direktorat Perlindungan Konsumen Ditjen Perdagangan Dalam Negeri Departemen Perindustrian dan Perdagangan Bekerjasama dengan Yayasan Gemainti.

[2] Taneko, Soleman B. 1993. Pokok-Pokok Studi Hukum Dalam Masyarakat. Jakarta: Penerbit PT Raja Grafindo Persada.

[3] Mertokusumo, Sudikno. 1984. Bunga Rampai Ilmu Hukum. Yogyakarta: Penerbit Liberty.

[4] Wignjosoebroto, Soetandjo. 2002. Hukum, Paradigma, Metode dan Dinamika Masalahnya. Jakarta: Penerbit ELSAM.

[5] Friedman, Lawrence M. 1977. Law and Society: An Introduction, Englewood Cliffs. New Jersey: Prentice Hall, Inc.

[6] Soekanto, Soerjono. 1982. Kesadaran Hukum dan Kepatuhan Hukum, Edisi Pertama. Jakarta: CV Rajawali.

[7] Soekanto, Soerjono. 1985. Efektivikasi Hukum dan Peranan Sanksi. Bandung: Penerbit CV Remaja Karya. 